\title{
International Journal of Nursing and
}

Health Services (IJNHS)

http://ijnhs.net/index.php/ijnhs/home

Volume 3 Issue 6, December 20 ${ }^{\text {th }}, 2020$, pp 687-694

e-ISSN: 2654-6310

\section{The Effectiveness of Acupressure and Smart Gymnastic on Fasting Blood Sugar Levels among Patients with Type II Diabetes Mellitus}

\author{
Dian Apri Nelyanti ${ }^{*}$, Ta'adi², M. Choiroel Anwar ${ }^{3}$ \\ 1. Nursing Student, Postgraduate Program, Master of Applied Health \\ 2. Politeknik Kesehatan Kemenkes Semarang, Semarang, Indonesia \\ 3. Politeknik Kesehatan Kemenkes Semarang, Semarang, Indonesia
}

\section{Article info}

\section{Article history:}

Received; July $15^{\text {th }}, 2020$

Revised: August $18^{\text {th }}, 2020$

Accepted: September $10^{\text {th }}, 2020$

\section{Correspondence author:}

Dian Apri Nelyanti

E-mail:

dianaprinelyanty22@gmail.com

DOI:

http://doi.org.10.35654/ijnhs.v3i6.368
Abstract. Diabetes mellitus (DM) is a glucose metabolisn disease characterized by an increase in blood sugar levels an impaired metabolism of fats, protein, and carbohydrates due $t_{t}$ a lack of the hormone insulin, both absolutely and relatively Alternative treatment of diabetes mellitus with complementar. therapies, namely acupressure and smart gymnastic, cal improve the fasting blood sugar level. This study aims ti determine the effectiveness of acupressure and smart gymnasti on fasting blood sugar levels among patients with type I diabetes mellitus. True experimental study pretest and post-tes with non-equivalent control group design were applied in thi study. Repeated Measure, ANOVA test, showed a significan difference with the mean fasting blood sugar level p-valu $0.000(<0.05)$. The intervention group is better at lowerin: fasting blood sugar levels than control group 1 and contro group 2 seen from the higher value difference. Conclusion o acupressure therapy with smart gymnastics three times a weel for four weeks effectively reduces fasting blood sugar level in patient with type II diabetes mellitus. This study can be used a a reference for further research, with a larger sample size controlling the patient's diet, and a longer duration $\mathrm{o}$ intervention, so that the results obtained are more valid.

Keyword: Acupressure, Smart Gymnastic, Fasting Blood Sugar Levels, Type II Diabetes Mellitus.

This is an Open Access article distributed under the terms of the Creative Commons Attribution 4.0 International License CC BY 4.0 


\section{INTRODUCTION}

Diabetes mellitus (DM) is a glucose metabolism disease characterized by increased blood glucose or hyperglycemia caused by defects in insulin secretion, insulin action, or both. DM is also referred to as a chronic disease characterized by increased blood sugar levels and disorders of the metabolism of fats, proteins, and carbohydrates caused by a lack of the hormone insulin in absolute or relative terms ${ }^{(1)}$.

Type I diabetes mellitus is diabetes caused by the destruction of pancreatic beta cells, which generally leads to absolute insulin deficiency due to autoimmune or more than $90 \%$ permanent damage to the pancreas. In contrast, type II diabetes mellitus is not caused by damage to the pancreas, and insulin is still produced. Even insulin levels increased from the standard limit is known as hyperinsulinemia. However, the insulin produced cannot carry glucose into the body's tissues due to a lack of insulin receptors ${ }^{(2)}$.

The International Diabetes Federation (IDF) in 2017 stated that there are 425 million people in the world living with DM, and it is estimated that around 175 million have not been diagnosed, so it is possible to develop into complications without realizing it and without prevention progressively. From this data, Indonesia is ranked 6th in the world, with 10.3 million people with diabetes. It is expected to continue to increase in 2030 to 21.3 million people, making Indonesia ranked 4th after China, India, and the United States. Type 2 diabetes mellitus is $90-95 \%$, which is the most common type of diabetes(3).

Based on the prevalence of diabetes mellitus in Indonesia, it is ranked 4th for chronic diseases. Basic Health Research Data (2018) of diabetes mellitus sufferers in Indonesia has increased from $6.9 \%$ in 2013 to $10.9 \%$ in 2018 . When viewed from an age perspective, the prevalence is mostly in the 45-65 years age range. The prevalence of diabetes mellitus sufferers in Central Java aged $\geq 15$ years was $2.1 \%$, or the number of patients was 96,794 people(4). In Semarang City, in 2017, diabetes mellitus is the second-highest noncommunicable disease after hypertension with 17,037 cases (5). .Based on previous research, in 2018, the prevalence of diabetes mellitus sufferers in the Srondol Community Health Center was 661 diabetes sufferers, with an average monthly visit of around 63 people ${ }^{(6)}$.

PERKENI (Indonesian Endocrinology Association, 2015) states that uncontrolled diabetes can have acute or chronic impacts or complications ${ }^{(7)}$. The difficulties of consisting of hypoglycemia, hyperglycemia, and diabetic ketoacidosis. In contrast, chronic complications include macro-vascular complications and microvascular complications. Diabetes mellitus often causes kidney failure, heart failure, stroke, diabetic ulcers, nephropathy, and neuropathy ${ }^{(8-9)}$.

Proper management of diabetes mellitus sufferers is needed to prevent complications. The five essential pillars of management are controlling the disease and complications, namely education, diet, physical activity, pharmacological therapy, and blood sugar control ${ }^{(10)}$. In addition to the five pillars, other alternative measures for people with diabetes mellitus are complementary therapies such as acupressure and physical activity in the form of gymnastic dodgy $^{(7,11)}$.

Acupressure is a form of traditional health care by stimulating specific points through pressure on the body surface using fingers or blunt objects to help health problems. The world health organization recognizes acupressure as a treatment to activate neurons in the nervous system, stimulating the endocrine glands to increase insulin secretion and turn on complex organs. Acupressure has been recognized as one of the nursing actions in the Nursing Intervention Classification and can be performed by nurses ${ }^{(12-13)}$.

The acupressure point used is SP 6 (San Yin Jiao), which is located on the cruris meridian three cun above the medial and posterior malleolus crest of the tibia, SP 10 (Xue Hai) is two cun above the patella on the protruding part of vastus medialis, and ST 36 (Zusanli) located three cun below the patella on one finger from the anterior shoulder of the tibia bone in the anterior tibia muscle. Acupressure can activate glucose-6-phosphate, which 
affects the hypothalamus and acts on the pancreas to increase insulin synthesis, expand one of the receptors on target cells, and accelerate the use of glucose in the cells ${ }^{(14)}$.

Previous research showed that acupressure effectively reduced blood sugar levels in people with diabetes mellitus with an average value of blood sugar levels after treatment in 122.23 with a $p$-value $(p=0.001)$ with an effect size of 0.58 (moderate). In line with previous research explained that acupressure at the ST-36 point could significantly reduce blood sugar levels with an average blood sugar level after treatment in the intervention group of 111.07

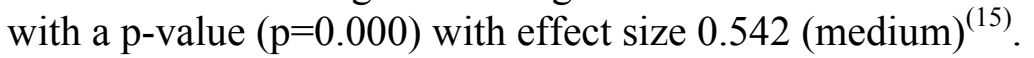

Another effort that can be made to overcome health problems is regular exercise. Types of exercise can be done in patients with diabetes mellitus, one of which is clever exercise. Smart gymnastics is a light and easy exercise that can be done by all ages. This exercise will help the body to stay in shape because it trains the body to remain strong, encourages the circulatory system to work appropriately, and eliminates free radicals in the body. Smart gymnastics is a government program to reduce complications and improve people's quality of life with non-communicable diseases. The word intelligent stands for regular health checks, gets rid of cigarette smoke, exercises diligently, has a healthy diet with balanced calories, gets enough rest, and manages stress ${ }^{(16-17)}$.

Previous research was conducted to determine differences in blood sugar levels before and after aerobic exercise (Low Impact) in the elderly pre DM. The results showed that the average blood sugar level of respondents in the elderly with Pre Diabetes Mellitus before doing aerobic exercise was $138.53 \mathrm{mg} / \mathrm{dL}$ after giving aerobic exercise for two weeks. The average blood sugar level of respondents with Prediabetes Mellitus was $120.62 \mathrm{mg} / \mathrm{dl}$ with a $\mathrm{p}$-value $=0.008(<0.05)$, meaning that there are different blood sugar levels before and after doing aerobic exercise in the elderly with pre-diabetes Mellitus (18).

Another study was conducted with the title, "Differences in the Effect of Aerobic Exercise and Yoga on Decreasing Blood Sugar Levels in Type II Diabetes Mellitus Patients at the Special Polyclinic of Internal Medicine M. Djamil Padang Central Public Hospital." The results of his research showed that the average decrease in blood sugar levels with aerobic exercise was $32 \mathrm{mg} / \mathrm{dl}$, and a moderate reduction with yoga was $47.7 \mathrm{mg} / \mathrm{dl}$. The results of the statistical test for the experimental and comparison group obtained $p$-value $=0.038(p<0.05)$, which means that aerobic exercise and yoga can reduce blood sugar levels in patients with type II diabetes. ${ }^{(19)}$

The above research results indicate that giving acupressure and giving physical activity can reduce blood sugar levels. Still, until now, the provision of smart exercise for people with diabetes mellitus on blood sugar levels has never been made research. Besides that, the community has not been familiar with acupressure therapy. They only know relaxation massage or full body massage. No research combines acupressure and clever exercise on blood sugar levels in diabetes mellitus sufferers. In this study, prospective researchers are interested in researching acupressure's effectiveness with smart exercise on fasting blood sugar levels in diabetics Mellitus type II.

\section{OBJECTIVE}

This study aims to determine the effectiveness of acupressure and smart gymnastic on fasting blood sugar levels among type II diabetes mellitus patients.

\section{METHODS}

A true experimental design pretest and post-test with non-equivalent control group design were applied in this study. Researchers allocated three groups, including the intervention group who received the acupressure therapy with smart gymnastic, the control 
group 1 received the acupressure therapy without smart gymnastics, and control group 2 received the acupressure therapy without smart gymnastics. Acupressure therapy and smart gymnastics were given three times a week for four weeks for a total of 12 meetings.

Examination of fasting blood sugar levels using an easy touch instrument measuring with the kiosherbalk u-KH89. The examination of fasting blood sugar levels of respondents with type II diabetes mellitus was carried out before (pretest) and after the therapy (post-test).

This study included all patients with type II diabetes mellitus in Srondol Semarang Public Health Center. Determining the minimum sample size using technique probability sampling with method simple random sampling and based on inclusion and exclusion criteria. Fifty-one respondents were divided into three groups, with 17 respondents allocated in the intervention group. Other seventeen respondents for the control group 1 who therapy acupressure without smart gymnastics. Whereas 17 respondents in the control group 2 (smart gymnastics without acupressure).

In this study, researchers collected data using observation, identification, interview, and filling out observation sheets. The collected data were analyzed through the IBM SPSS version 24.0 program and continued with a different test, namely the parametric test (Repeated Measure ANOVA test). The processed data is used to discuss the problem statement, which is then presented in tabular form to conclude.

\section{RESULTS}

Table 4.1 Frequency distribution of respondents from age, gender, education, and professionbased on demographic data

\begin{tabular}{|c|c|c|c|c|c|c|c|}
\hline \multirow[t]{2}{*}{ Characteristics } & \multicolumn{2}{|c|}{$\begin{array}{c}\text { Intervention } \\
(n=17)\end{array}$} & \multicolumn{2}{|c|}{$\begin{array}{c}\begin{array}{c}\text { Control } 1 \\
(n=17)\end{array} \\
\end{array}$} & \multicolumn{2}{|c|}{$\begin{array}{c}\text { Control } 2 \\
(n=17)\end{array}$} & \multirow{2}{*}{$\begin{array}{c}\text { P- } \\
\text { value }\end{array}$} \\
\hline & $\mathbf{N}$ & $\%$ & $\mathbf{N}$ & $\%$ & $\mathbf{N}$ & $\%$ & \\
\hline Age (mean \pm SD) & \multicolumn{2}{|c|}{$54.71 \pm 6.498$} & \multicolumn{2}{|c|}{$55.12 \pm 5.255$} & \multicolumn{2}{|c|}{$55.35 \pm 4.974$} & 0.271 \\
\hline Gender & & & & & & & 0.367 \\
\hline Male & 1 & 5.9 & 1 & 5.9 & 2 & 11.8 & \\
\hline Female & 16 & 94.1 & 16 & 94.1 & 15 & 88.2 & \\
\hline Education & & & & & & & 0.115 \\
\hline Elementary school & - & - & - & - & 1 & 5.9 & \\
\hline Junior High School & 1 & 5.9 & 3 & 17.6 & 3 & 17.6 & \\
\hline Senior High School & 14 & 82.4 & 14 & 82.4 & 12 & 70.6 & \\
\hline College & 2 & 11.8 & - & - & 1 & 5.9 & \\
\hline Profession & & & & & & & 0.120 \\
\hline IRT & 12 & 70.6 & 13 & 76.5 & 13 & 76.5 & \\
\hline Entrepreneur & 1 & 5.9 & 2 & 11.8 & 2 & 11.8 & \\
\hline Trader & 2 & 11.8 & 2 & 11.8 & 1 & 5.9 & \\
\hline Does not work & 2 & 11.8 & - & - & 1 & 5.9 & \\
\hline Total & 17 & 100 & 17 & 100 & 17 & 100 & \\
\hline
\end{tabular}

Table 1 showed respondents' characteristics that age, gender, education, and profession in the intervention group, control group 1 and control group 2 have the same significant value p-value $>0.05$ means the same or homogeneous. The sex of the three groups was mostly female, the education of respondents was primarily high school, and the profession was mainly housewives. 
Table 4.2 Analysis of the difference in mean fasting blood sugar levels between the intervention group, control group 1, and control group 2

\begin{tabular}{lcrrrr}
\hline \multicolumn{1}{c}{ Measurement } & $\begin{array}{c}\text { Type III sum } \\
\text { of squares }\end{array}$ & Df & $\begin{array}{c}\text { Mean } \\
\text { Square }\end{array}$ & f & $\boldsymbol{P}$ \\
\hline Between-subjects effects & 14496.376 & 2 & 20748.188 & 14.397 & 0.000 \\
\hline *Repeated Measure ANOVA test & & & &
\end{tabular}

Based on the table above shows that there was a change in fasting blood sugar levels after being given acupressure and smart gymnastic within 26 days ( 4 weeks) with a duration of 3 times a week with a significance value of $p$-value $<0.05(p=0.000)$. It was indicated that acupressure and smart gymnastic effectively reduced sugar levels fasting blood in patients with type II diabetes mellitus.

Table 4.3 Analysis of the effectiveness of acupressure and smart gymnastic on reducing fasting blood sugar levels in the intervention group, control group 1, and control group 2

\begin{tabular}{ccccc}
\hline Variable & Group & Mean & SD & $\boldsymbol{P}$ \\
\hline GDP post week 1 H3 & Intervention & 146.06 & 19.201 & 0.013 \\
& Control 1 & 164.35 & 19.758 & \\
& Control 2 & 162.82 & 17.515 & \\
\hline GDP post week 2 H10 & Intervention & 116.65 & 13.597 & 0.000 \\
& Control 1 & 154.36 & 19.290 & \\
& Control 2 & 151.94 & 16.969 & \\
\hline GDP post week 3 H19 & Intervention & 100.82 & 10.436 & 0.000 \\
& Control 1 & 144.06 & 18.518 & \\
& Control 2 & 142.00 & 16.313 & \\
\hline GDP Post week 4 H26 & Intervention & 89.00 & 8.367 & 0.000 \\
& Control 1 & 136.12 & 18.493 & \\
& Control 2 & 134.12 & 14.221 & \\
\hline
\end{tabular}

*General Linear Model test

The table above shows that after being given treatment between intervention groups, control group 1 and control group 2 showed a decrease in fasting blood sugar levels. After being given treatment for four weeks three times a week, a decrease in fasting blood sugar levels was significant with a $\mathrm{p}$-value $<0.05$. In-group intervention, there was a significant reduction after treatment was given at week 1 (post-week $1 \mathrm{H} 3$ ) to week four treatment (postweek $4 \mathrm{H} 26)$ with a $\mathrm{p}$-value $<0.05$ ( $\mathrm{p}=0.000)$ including normal fasting blood sugar levels. Whereas control group 1 and control group 2 also experienced a decrease in fasting blood sugar levels with a significant $p=0.000$. Still, there was a decrease when viewed from the mean value, but the reduction had not reached the standard limit.

\section{DISCUSSION}

The multivariate analysis used in this study was the Repeated Measure ANOVA test. The statistical analysis results showed that the mean value of fasting blood sugar levels in the intervention group and the control group had a significant difference with a value of $p=0.000$. It was indicated that the provision of clever exercise followed by giving acupressure to the intervention group was more effective at reducing fasting blood sugar levels in a patient with type 2 diabetes mellitus.

This can be seen from the results of the study that after being given treatment in each group with a duration of 3 times a week for four weeks, they both experienced a decrease in 
fasting blood sugar levels is $89.00 \mathrm{mg} / \mathrm{dl}$ in the intervention group, $136.12 \mathrm{mg} / \mathrm{dl}$ in the control group 1 and 134.12 in the control group 2 with a $p$-value $(p=0.000)$.

In this study, it can be said that all interventions in each group are effective against reducing fasting blood sugar levels. Still, the group, the most experienced reduction in fasting blood sugar levels was in the intervention group. Therefore, the conclusion acupressure and smart exercise interventions effectively reduced fasting blood sugar levels in people with type II diabetes mellitus.

The research was conducted by providing acupressure and exercise acupressure to type II diabetes mellitus sufferers. Acupressure was given 3 times a week for 4 weeks at 3 points, namely SP6, SP10, and ST36, with a duration of 2 minutes each point. Common acupressure release neurotransmitters that carry signals along nerves or through glands that activate the hypothalamus. According to Ingel (2011), acupressure can activate glucose six phosphates. One of the essential enzymes in carbohydrate metabolism affects the hypothalamus, thereby reducing blood glucose levels.

In line with Firullah \& Rousdy (2017) research, acupressure carried out at SP6, and ST36 points can reduce blood sugar levels in a patient with type 2 diabetes mellitus. Emphasis on these points can restore the balance of the meridians Yin and Yang increase insulin secretion in non-insulin-dependent diabetes mellitus sufferers. Focus on acupressure points SP6 and ST36 can activate glucose six phosphates, a carbohydrate metabolism enzyme. Besides that, it also activates Hypothalamus-pituitary-Adrenal AXIS and produces the hormone Corticotrophin Releasing Factor (CRF) to stimulate the pancreas to increase insulin synthesis. One of the target cell receptors is the glucose transporter (GLUT 4), which carries glucose into cells and accelerates glucose use, thereby reducing blood sugar levels. In addition to acupressure, other non-pharmacological therapies can lower blood sugar levels, namely, by doing physical activity in creative exercise ${ }^{(20)}$.

Gymnastics that are done regularly can help you lose weight, which is a risk factor for diabetes mellitus. It is followed by a healthy lifestyle, such as eating healthy and nutritious foods. Following previous research, this says that lifestyle changes and gymnastic routine can reduce the risk of diabetes mellitus. This occurs because physical activity potentiates gymnastic on insulin sensitivity with the AMPK (Activation Mechanism AMP-Protein Kinase), which works by regulating glucose uptake and insulin sensitivity by increasing the amount of GLUT4, which results in reduced insulin resistance and increased muscle uptake and sugar intake. Improve insulin use, which results in decreased levels of postprandial blood sugar and fasting blood sugar. This shows that smart gymnastics can increase the sensitivity of the body's cells to insulin to reduce blood sugar levels, bad cholesterol (LDL), and good cholesterol (HDL) levels ${ }^{(21)}$.

In line with the research conducted by Harmilan (2019) that there is an effect of prolanic gymnastic given for four weeks two times a week with a duration of 40 minutes on reducing blood sugar levels in people with type 2 diabetes mellitus with the lowest value after being given treatment in the fourth week is $98 \mathrm{mg} / \mathrm{dl}$. The highest value was $178 \mathrm{mg} / \mathrm{dl}$. The average decrease before and after prolanic gymnastics was $14,625 \mathrm{mg} / \mathrm{dl}{ }^{(22)}$. Another study also explained the positive effect of exercise on blood glucose level (23-24)

The current study showed acupressure and creative exercise for 4 weeks with a duration of 3 times a week effectively reduces fasting blood sugar levels in people with type II diabetes mellitus.

\section{CONCLUSION}

Based on data processing and analysis on acupressure and smart gymnastic effectiveness as an alternative to complementary therapy. It can be concluded that the mean reduction in fasting blood sugar levels in the intervention group is more than the mean decrease in fasting blood sugar levels in the control group 1 and control group 2 with p-value 
$<0.05$. In conclusion, the intervention group is better at lowering fasting blood sugar levels than control group 1 and control group 2.

Interventions related to acupressure and smart gymnastic have been proven effective in reducing fasting blood sugar levels in type II diabetes mellitus sufferers. The research results are expected to be applied by nurses as a non-pharmacological treatment to prevent and treat type II diabetes mellitus patients. This study can be used as a reference for further research, with a larger sample size, controlling the patient's diet, and a longer duration of intervention, so that the results obtained are more valid.

\section{REFERENCES}

(1) Andreassen LM, Sandberg S, Kristensen GBB, Sølvik UØ, and Kjome RLS. Nursing home patients with diabetes: prevalence, drug treatment, and glycemic control. Diabetes research and clinical practice. 2014; 105: 102-9.

(2) Afriza A. Pengaruh Senam Diabetes Terhadap Kadar Glukosa Darah Pada Penderita Diabetes Mellitus Di Puskesmas Lapai Kecamatan Nanggalo Kota Padang. Jurnal Ilmu Keolahragaan. 2015; 1.

(3) Cho N, Shaw J, Karuranga S, et al. IDF Diabetes Atlas: Global estimates of diabetes prevalence for 2017 and projections for 2045. Diabetes research and clinical practice. 2018; 138: 271-81.

(4) Kementrian Kesehatan Republik Indonesia. Riset Kesehatan Dasar (Riskesdas 2018). Jakarta: Balai Penelitian dan Pengembangan Kesehatan, 2018.

(5) Dinas Kesehatan Kota Semarang. Profil Kesehatan Kota Semarang 2017,.2018.

(6) Kurniati Ainun S, Djamil Masrifan. The effectiveness of self-ACU yoga to words fasting blood sugar levels in type II diabetes mellitus patients. Semarang: IJAMSCR, 2019.

(7) Indonesia PE. Pengelolaan dan Pencegahan Diabetes Melitus Tipe 2 Di Indonesia. $P B$ PERKENI. 2015.

(8) Dewi RK and Gz S. Diabetes bukan untuk ditakuti. FMedia, 2014.

(9) Eliana F, SpPD K and YARSI B. Penatalaksanaan DM Sesuai Konsensus Perkeni 2015. PB Perkeni Jakarta. 2015.

(10) Ernawati. Penatalaksanaan Keperawatan Diabetes Melitus Terpadu Dengan Penerapan Teori Keperawatan Self Care Orem. Jakarta: Mitra Wacana Media, 2013.

(11) Damayanti S. Diabetes Mellitus \& Penatalaksanaan Keperawatan. Yogyakarta: Nuha Medika, 2016.

(12) Masithoh RF, Ropi H and Kurniawan T. Pengaruh Terapi Akupresur Terhadap Kadar Gula Darahpada Pasien Diabetes Melitus Tipe Iidi Poliklinik Penyakit Dalam RS Tk II Dr. Soedjono Magelang. Journal Of Holistic Nursing Science. 2016; 3: 26-37.

(13) Butcher HK, Bulechek GM, Dochterman JMM, and Wagner CM. Nursing Interventions Classification (NIC)-E-Book. Elsevier Health Sciences, 2018.

(14) Oktaviani R, Mardiyono $M$ and Achiriyati D. Acupressure On Zusanli (St36) And Taibai (Sp3) in Reducing Nausea for Patients with Dyspepsia at Banyumas Hospital. 2014. 2014; 4: 9.

(15) Jumari J, Waluyo A, Jumaiyah W and Natashia D. Pengaruh Akupresur terhadap Kadar Glukosa Darah Pasien Diabetes Melitus Tipe 2 di Persadia RS Islam Jakarta Cempaka Putih. Journal of Telenursing (JOTING). 2019; 1: 38-50.

(16) Pambudi RS and Khusna K. Tingkat Pengetahuan Program CERDIK dan Informasi Obat Pada Pasien Hipertensi Di Puskesmas X Surakarta. Journal of Pharmaceutical Science and Medical Research. 2019; 2: 69-76.

(17) Utomo AS. Pemberdayaan Lansia Dalam Menumbuhkan Perilaku Cerdik Mencegah Stroke. Jurnal IDAMAN (Induk Pemberdayaan Masyarakat Pedesaan). 2018; 2: 1-6. 
(18) Arovah NI, Ch Fajar Sriwahyuniati MO and Erlina Listyorini. Pengembangan model senam yoga untuk kontrol glukosa darah dan menurunkan resiko komplikasi penderita diabetes mellitus tipe 2 (suatu tinjauan klinis dan sosio-psikologis). Yogyakarta: Universitas Negeri Yogyakarta, 2013;3: 7-19.

(19) Fatia N. Perbedaan pengaruh senam aerobik dan yoga terhadap penurunan kadar gula darah pada pasien diabetes mellitus tipe II di poliklinik khusus penyakit dalam RSUP M. Djamil Padang tahun 2012. Padang. Universitas Andalas Press, 2014;3

(20) Rousdy A. Effectiveness of acupressure at the Zusanli (ST-36) acupoint as a comfortable treatment for diabetes mellitus: a pilot study in Indonesia. Journal of Acupuncture And Meridian Studies. 2017; 10: 96-103.

(21) Jamaluddin M and Prasetyo WM. Terapi akupresure terhadap keseimbangan glukosa darah pada pasien dm tipe 2 di wilayah kerja puskesmas ujumpandang baru Makassar. Media Kesehatan Politeknik Kesehatan Makassar. 2019; 14: 181-5.

(22) Casman C, Fauziyah Y, Fitriyana I and Triwibowo C. Perbedaan Efektifitas Antara Latihan Fisik Dan Progressive Muscle Relaxation (Pmr) Terhadap Penurunan Kadar Gula Darah Puasa Pada Penderita Diabetes Melitus Tipe 2. Jurnal Ilmiah PANNMED (Pharmacist, Analyst, Nurse, Nutrition, Midwivery, Environment, Dentist). 2015; 10: 246-9.

(23) Pamungkas RA, Chamroonsawasdi K. Self-management based coaching program to improve diabetes mellitus self-management practice and metabolic markers among uncontrolled type 2 diabetes mellitus in Indonesia: A quasi-experimental study. Diabetes \& Metabolic Syndrome: Clinical Research \& Reviews. 2020; 14 (1), 53-61

(24) Pamungkas RA, Chamroonsawasdi K. Family Functional-based Coaching Program on Healthy Behavior for Glycemic Control among Indonesian Communities: A Quasiexperimental Study. Oman Medical Journal. 2020; 35 (5), e173 